\title{
Reviews on the Contributions of Micro and Small Business Enterprise and Performance in Ethiopia. Reviews Paper
}

\author{
Anuto David Ojulu \\ Department of Agricultural Economics, Gambella University, Gambella, Ethiopia
}

\begin{abstract}
Micro and Small Enterprises (MSEs) play an important economic role and recognized as an important vehicles of employment creation, income generation and poverty alleviation. The purpose of this article reviews was to reviews the contribution of MSEs and it factors constraining the growth of micro and small business (MSEs) growth in Ethiopia. The reviews were based on the secondary data that are published on the micro and small business in Ethiopia. The several authors argue that employment generation by the small business may be high in quantitative term but very low in quality. Technological up-gradation would enable the small firms to create quality employment improving remuneration, duration and skill. This structural shift may reduce the rate of employment generation in the short run but would ensure high-income employment generation in the long run. Furthermore, It provides employment opportunities, encourages and sustains self-reliance, provides technical inventions and innovations promotes competition in the market which acts as a check in the activities of monopolists, utilize waste product from big firm for further production. Therefore, this article reviews shows that poor government regulation, evaluation, follow, working premises, initial investment, high collateral requirement from financial institutions, lack of clear job description among members, lack of training, poor linkage of MSEs to the market, were some infrastructural, managerial, financial, legal, and marketing challenges as factors affecting the growth of MSEs in Ethiopia. Therefore, the concerned office should support the MSEs to tackle factors hindering its growth. MSEs should tie to the market and members should develop culture of working together for the growth of SMEs.
\end{abstract}

Keywords: Micro business, Economic Growth, Challenge, Employment, Empowerment, Ethiopia

DOI: $10.7176 / \mathrm{JESD} / 12-15-05$

Publication date:August $31^{\text {st }} 2021$

\section{Introduction}

The Micro and Small Enterprises are the back bones various economies across the world. Therefore, it contributes to the development of many countries economy. Accordingly, small business enterprises it dynamic for job creation, source of wealth for owner, source of income for government in GDP and government also give attention to them. Moreover, the small business and medium enterprises play crucial role in the Ethiopian economy because it is mechanism to stimulate economic growth, thereby employment creation in the country. Therefore, the significant of the Small business and Medium Enterprises are increasingly become widespread and also played vigorous role in Ethiopian economy as they are able to decisive role to employment generating, poverty reduction and opening broader distribution of wealth and opportunities in the country (Abebaw et al., 2018). It's commonly well-known that the micro and small Enterprises (MSES) have vigorous contribution to the economic development and creation of the wide employment opportunity in the developing countries with large number of unemployed people. People without high-level training, a lot of money, and sophisticated technology, according to Habtamu, Aregawi, and Nigusu (2013). These factors make the industry more appealing for new business start-ups, job creation, income generating, and poverty reduction.

The achievement of the government and country in favor to business development is associated to small business sustainability (Carrasco-Davila, 2005). Thus, the local and federal authorities had been developing program that promote the creation of new job through the small business (Plan Nacional, de Desarrollo, 2007 cite by Gemech et al., 2016). Thus, small business sector is recognized as an integral component of the economic development and crucial element in effort to lift countries out circulated gossips. The dynamic function of small business companies in developing nations as engines for achieving developing countries' growth objectives has long been acknowledged. As a result, small companies play a significant part in the country's growth and serve as a way of sustaining and growing economies (Ibrahim \& Parsa, 2008). Small business is popular because it is simple to set up and operate.

Small business contributes lowering unemployment as well as generate new source of employment. Small business contribute to over $60 \%$ of GDP and over $70 \%$ of total employment in low income countries, according to the World Economic Forum on Small Business. The World Trade Organization estimates that small business contributes trillion a year to the global economy.

Empirical literature reviews in Ethiopia on Micro and Small Enterprises

As a result, reforming rules that split the informal and formal sectors is a key policy objective in developing 
countries, allowing the poor to join in the market and engage in higher-value-added economic activities (Ayyagari, Beck and Demirguc-kunt, 2003). As a result, both developed and developing countries have programs to encourage the growth of small businesses (Storey, 1994, Levitsky, 1996, Hallberg, 2000). As a result, in industrialized countries, it has been commonplace for governments to enact policies or programs aimed at promoting parts of small company enterprise over the last two or three decades (Gemechu et al., 2016). According to the authors, it has coincided with an increase in the importance. For example, in most industrialized economies, small and medium businesses contribute to employment and GDP growth (Storey, 1994 cite by Gemech et al., 2016).

\subsection{The contribution of the Micro and Small Enterprises to the employment}

Small and medium businesses contribute to the well-being of both individuals and nations. As a result, it creates jobs and enhances the standard of living for both the employer and the employee. The nation, on the other hand, complements large-scale modern-sector firms and provides Ethiopians with the required platform for entry into large-scale modern production. The authors argued that, it has coincided with the increase in the important. According to the authors, it has coincided with an increase in the importance. For example, in most industrialized economies, small and medium businesses contribute to employment and GDP growth (Storey, 1994 cite by Gemech et al., 2016). The current economic reform process in Ethiopia, which aims to reduce poverty, unemployment, and strengthen basic institutions and sub-sectors of the economy with the goal of improving and enhancing the capacity of small scale enterprises, is beginning to restore faith in small scale enterprises as a source of economic growth and development (Mohammed et al., 2016). Furthermore, it made a significant contribution to the country's socioeconomic development (Gelgelu et al., 2018). As a result, small businesses in general, and new businesses in particular, play an essential role in tackling socioeconomic issues such as unemployment, poverty, and income, political, and economic growth, to name a few (Musara \& Gwanindepi, 2014). Furthermore, it made a significant contribution to the country's socioeconomic development (Gelgelu et al., 2018). As a result, small businesses in general, and new businesses in particular, play an essential role in tackling socioeconomic issues such as unemployment, poverty, and income, political, and economic growth, to name a few (Musara \& Gwanindepi, 2014). For example, the health of the micro and small business sector is critical for overall economic growth because they make use of local resources, meet vital needs of a large segment of the population with their products and services, serve as a source of technological, marketing, and management capacity and skill acquisition, and enable technology adoption through technology adoption (FeMSEDA, 2014).

Small businesses create more jobs and earn more money, thus they not only help to alleviate poverty, but they also improve the welfare and standard of living of many people (Mulugeta, 2011 as cited by Mesert Meresa, et al., 2018). The labor they get as a small company owner or employee allows them to create for themselves (i.e. food) and earn the money they need to acquire goods and services. As a result, poverty reduction and employment creation are linked. Work that generates income through taxation, according to Goshu et al., (2015), allows the government to support pro-poor services such as health care, clean water, and education. Teferal et al., (2013), on the other hand, discovered that small scale business companies can stimulate socioeconomic resurrection because they require little capital to operate but can contribute significantly to work with minimal simple and inexpensive equipment. On other hand, a study conducted by (Bhavani T.A., 2010), highlights that the issue of quality employment generation by the Small business and negates the short term attitude of increasing the volume of employment generation compromising with quality. The author argues that employment generation by the small business may be high in quantitative term but very low in quality.

Technological up-gradation would enable the small firms to create quality employment improving remuneration, duration and skill. This structural shift may reduce the rate of employment generation in the short run but would ensure high-income employment generation in the long run. Furthermore, small and mediumsized businesses play critical roles in a country's economic growth and development. It creates jobs, fosters and supports self-sufficiency, provides technical ideas and innovations, promotes market competition, which acts as a check on monopolists' activities, and recycles trash from large companies for continued production. Small business and Medium Enterprises has emerged as a powerful tool in providing relatively large employment base for given unit of investment, equitable wealth distribution and removal of regional economic disparities (Getahun et al., 2016). They are found to be one of the most reliable economic development and livelihood strategy, especially during economic turbulence (Kamoyo et al., 2014). Small and medium enterprises, in general, and new businesses, in particular, play an important role in tackling socioeconomic issues such as unemployment, poverty, income inequality, political stability, and economic growth, to name a few (Abera., 2012).

The contribution of small and medium businesses to the economy has an impact on other sectors, and as a result, SMEs serve as an engine of economic growth. As a result, SMEs act as a counterbalance to monopolies, reducing the ability of large corporations to control the market. SMEs are responsible for a bigger proportion of the technical innovation that is used in the economy. The importance of SMEs in Ethiopia is shown in the 2014 
Economy Survey, which revealed that the informal sector, which is dominated by SMEs, accounted for 83 percent of the 800,000 employment created in 2014. (Goshu, et al., 2015).

Economic empowerment refers to women and men's ability to participate in, contribute to, and benefit from economic processes in ways that value their contributions, respect their dignity, and allow for a more equitable distribution of growth benefits (Eyben et al., 2008). As a result, women will have greater access to economic resources and opportunities, such as jobs, financial services, property and other productive assets, skill development, and market knowledge.

Though women's participation in community development projects and productive activities like as farming, paid domestic work, services, industries, and other income-generating activities is better than in the past, there is still a problem in terms of their empowerment in Ethiopia (Anuto D et al., 2020).

\subsection{The challenge of Micro and Medium Enterprises}

Despite their contributions to economic development and employment creation, micro and small businesses face a slew of challenges that stymie their growth and development. For example, Belay (2015) analyzed factors that influence the development of micro and small businesses in the Ethiopian towns of Mettu, Hurumu, Bede-lle, and Gore. His findings revealed that the primary bottlenecks include a lack of experience, promotion, access to finances, weak infrastructures, a lack of expertise, a lack of professional support, a lack of awareness of creditgranting institutions, and a lack of market linkage. Admasu (2015) investigated the prospects and problems of small business businesses in Ethiopia's Gedio Zone. Furthermore, his research found that excessive taxes, a lack of finance, a regulatory load, and a lack of company premises are the key issues that small businesses face. Mohammed (2016) looked at the problems and opportunities of small-scale business in Addis Ababa, Ethiopia. Insufficient money, poor infrastructures, bad management practices, and double taxation were the most significant issues affecting small businesses in Ethiopia, according to his research. On the other hand, small business owners who fail to keep proper books of accounts for their company have been found to have poor record-keeping skills. Similarly, the inability to manage books of accounts was determined to be due to a shortage of skilled accountants. He also discovered that 4 percent and 2.2 percent of respondents said that others and books of accounts are not essential, respectively. His conclusion is that, in terms of keeping books of accounts for better financial management, the majority of the owners did not do so due to a lack of accounting abilities. Furthermore, the authors discovered that the most significant obstacle for small business owners is a lack of financing, as well as a lack of financial and marketing management abilities, a lack of selling skills, and a lack of customer communication skills (Solomon, 2019).

Although a number of obstacles obstruct MSE growth, the most serious issue is destructive rent-seeking behavior, which can take several forms. Access to technology, expertise, capital funding, and markets are among the other problems that MSEs face (FDRE MUDC, 2016).

Commercial banks are not allowed to use more than $25 \%$ of their capital for a single borrower and $15 \%$ of their entire capital for a connected party, according to Ethiopia Bank of Ethiopia instruction number. SBB/53/2012. Similarly, MFIs are not allowed to use more than $1 \%$ of their capital for individuals who can offer collateral, and not more than $4 \%$ of their capital for group collateral, according to the National Bank of Ethiopia order no. MFI/18/06. Private banks were subjected to lending restrictions, which were later replaced by a directive from the National Bank of Ethiopia (MFA/NBE Bills/001/2011), which requires commercial banks to set aside $27 \%$ of total loan disbursed during the month for the purchase of low-interest-bearing National Bank of Ethiopia bills. The National Bank of Ethiopia's bill purchase requirement continues to stifle private commercial bank activities, favoring existing, well-established clients over newer, riskier small and medium-sized businesses when it comes to loan allocation (Fredu Nega and Edris Hussein, 2016). Similarly, Belay et al. (2015) discovered that a lack of water supply, reliable power supply, transportation facilities (infrastructure challenges), interest rate, lack of access to information on business opportunities, and the lack of state-of-the-art machinery and equipment are all factors that affect business opportunities. business skill gaps, youths' negative attitude toward working in small scale and medium Scale Enterprises and consumers perception.

\section{Role of Micro Business and Medium Enterprises in Ethiopia}

The creation and support of small and medium businesses play a critical part in the country's efforts to reduce youth unemployment, as the country's demographics are dominated by young people. Job creation is a primary goal of all medium and small businesses in Ethiopia. The construction sector ranks first in terms of total jobs created, followed by the service sector, which ranks second in terms of total jobs created. Manufacturing, which is the focus of MSE policy and strategy, ranks third in terms of total jobs created during the specified period. The last spot goes to urban agriculture. As a result, the author concluded that, although receiving more attention and support, the manufacturing sector is falling behind other sectors in terms of employment creation. 


\section{CONCLUSIONS}

Several scholars claim that while small businesses generate a lot of jobs, the quality of those jobs is often poor. Small businesses would be able to produce more quality jobs as a result of technological advancements, which would improve compensation, duration, and skill. This structural adjustment may slow the rate of job creation in the short term, but it will secure high-income job creation in the long run. Furthermore, small and medium-sized businesses play critical roles in a country's economic growth and development. It creates jobs, stimulates and supports self-sufficiency, provides technical ideas and innovations, promotes market competition, which acts as a check on monopolists' actions, and recycles trash from large corporations for continued production. Poor government regulation, evaluation, follow, working premises, initial investment, and high collateral requirement from financial institutions, lack of clear job description among members and lack of training were some factors affecting the growth of MSEs in Ethiopia, according to an article review by The Ethiopian Broadcasting Corporation. Therefore, the concerned office should support the MSEs to tackle factors hindering its growth.

\section{References}

Abera, A. (2012). Factors Affecting the Performance of Micro and Small Enterprises in Arada and Lideta SubCities, Addis Ababa.

Ayyagari, Meghana., Thorsten Beck, Asli Demirgüc Kunt (2003), "Small and Medium Enterprises Across the Globe", World Bank Policy Research Working Paper 3127, August, Washington D.C

Bhavani, T.A. (2011), "Dynamic Business Environments: What These Mean for Indian Small Enterprises" in "Micro and Small Enterprises in India: Era of Reforms: Keshab Das (Ed)" pp. 27-45

Carrasco-Davila, A.F. 2005. La micro yequeria empress amexicana (Micro and small Mexican business). Observation de la Economia latino Americana, 45. Retrieve from http://www.eumed.net /cursecon/ecolat/mx/2005/afcd-mpymem.htm

Deksiso Guye Gelgelu. Assessment of the factors affecting the performance of micro and small scale enterprise: the case of Wolkite town, Guraghe zone, southern Ethiopia. Journal of Development and Agricultural Economic. DOI: 10.5897/JDAE2017.0899 Vol. 10(6), pp. 192-199, June 2018

Federal Democratic Republic of Ethiopia Ministry of Trade and Industry Micro and Small Enterprise Developme nt Strategy, 2014, Addis Ababa, Ethiopia.

Gemechu Abdissa and Teklemariam Fitwi, (2016). Factors affecting performance of micro and small enterprises in south western Ethiopi; the case of Bench Maji, Sheka, and Kefa zone. Global journal of management and business research: A Administration and management Vol 16(10). Online ISSN: 2249-5688 \& print ISSN: 0975-5853

Goshu, F. (2015). Determinants of Micro and Small Enterprises Growth in Ethiopia: The Case of Nekemte Town of Oromia Region, Ethiopia. European Journal of Business and Management, 7(13), 92-105.

Goshu, F. (2015). Determinants of Micro and Small Enterprises Growth in Ethiopia: The Case of Nekemte Town of Oromia Region, Ethiopia. European Journal of Business and Management, 7(13), 92-105.

Habtamu, T., Aregawi, G. and Nigus, A. (2013). Growth Determinants of micro and Small Enterprises: Evidence from Northern Ethiopia. Journal of Economics and Sustainable Development, 4(9), 128-135.

Ibrahim, N. A., Angelidis, J. P., \&Parsa, F. (2008). Strategic management of family businesses: Current findings and directions for future research. International Journal of Management, 25(1), 95 110. Retrieved from Pro Quest database. (Document ID: 1460961721).

Jemal Abagissa, (2021).The assessment of micro and small enterprises performance and challenge in Addis Ababa, Ethiopia. International journal of applied Economic, Finance and Accounting. ISSN 2577-767X. Vol.9,No.1,pp.8-18.Doi:10.33094/8..2017.2021.91.8.18.

Mohammed Getahun, (2016). The Challenge and Prospects of Small Scale Enterprise in Ethiopia: A Survey of Some Selected Small Scale Enterprise in Addis Ababa City. International Journal of Scientific and Research Publications, Vol (6), 617-626.

Mohammed Getahun. The Challenge and Prospects of Small Scale Enterprise in Ethiopia: A Survey of Some Selected Small Scale Enterprise in Addis Ababa City. International Journal of Scientific and Research Publications, Volume 6, Issue 5, May 2016617 ISSN 2250-3153

Mulugeta Yohanes. (2011). The Livelihoods Reality of Micro and Small Enterprise Operators: Evidences from Woreda One of Lideta Sub-City, Addis Ababa. MA Thesis in Regional and Local Development Studies. RLDS, Addis Ababa University.

Solomon, T. (2019). Assessment of Critical Challenges Facing Small Business Enterprises: A Survey of Small Businesses in Woliso Twon, Ethiopia. Research Journal of Finance and Accounting ISSN 2222-1697 (Paper) ISSN 2222-2847 (Online). Vol.10, No.3, 2019. DOI: 10.7176/RJFA

Storey, D.J. (1994), Understanding Small Business Sector, London: Rout ledge. Symeonidis, George (2000), "Pr ice Competition and Market Structure: The Impact of Cartel Policy on Concentration in the UK", Journal of Industrial Economics, Vol. 48 No. 1, March, 1-26. 
Tefera, H., Gebremichael, A., \& Abera, N. (2013). Growth Determinants of Micro and Small Enterprises: Evidence. Journal of Economics and Sustainable Development, 4(9).

Woldetsadik Kagnew Abebaw, Ssay Mulate, Lemma Nigussie. Factors Affecting the Performance of Micro and Small scale Enterprises: Experience from North Shewa Zone, Ethiopia. Journal of investment and management. Vol.7. No. 2, 2018. Pp.70-76. doi:10.1164/j.jjim.20180702.14. 